\title{
ECOLOGICAL STUDIES ON SOME PIERCING-SUCKING INSECTS INFESTING COWPEA AT EL-SHARKIA GOVERNORATE, EGYPT
}

\author{
EL-KHAYAT, E. F. ${ }^{1}$; RASHA A. EL-HOSSEREY ${ }^{1}$ and ASMAA A. A. FADL ${ }^{2}$
}

1. Plant Protection Department, Faculty of Agriculture, Benha University, Egypt

2. Plant Protection Research Institute, ARC, Giza, Egypt

(Manuscript received $2^{\text {nd }}$ October 2016)

\begin{abstract}
$\mathrm{T}$

he present work was conducted during 2012 and 2013 seasons to survey the Hemipterous insects, aphids, leafhoppers and whiteflies infesting cowpea crop at AboHammad district, El-Sharkia governorate, Egypt. The seasonal abundance of the aforementioned dominant species and the effects of maximum \& minimum temperatures and relative humidity on the pest population were also studied. Plant samples collecting proved to be the most efficient method for collecting aphids and whiteflies, while the sweeping net is more efficient for collecting leafhoppers. A. craccivora, A. gossypii, E. decipiens, E. decedens, C. chinai and $B$. tabaci were surveyed. $A$. craccivora recorded one peak at the $4^{\text {th }}$ week of July in the two study seasons. A. gossypii recorded one peak at the $2^{\text {nd }}$ week of August in 2012 season. In the second season, 2013, two peaks were recorded in the $4^{\text {th }}$ week of July and the $2^{\text {nd }}$ week of August, respectively. E. decipiens recorded two peaks, the first one was recorded at the $3^{\text {rd }}$ and $4^{\text {th }}$ week of July for 2012 and 2013 seasons, respectively, while the second one occurred at the $3^{\text {rd }}$ week of August for the two seasons, respectively. E. decedens recorded two peaks at the $4^{\text {th }}$ week of July and August for the two seasons, respectively. Two peaks for immature $B$. tabaci were recorded. The first peak was obtained at the end of July for the two seasons of the study. The second one was noticed at the $3^{\text {rd }}$ week of August for the two seasons. Adults of $B$. tabaci recorded the first peak at the $3^{\text {rd }}$ week of July for 2012 and 2013 seasons. Their second peak occurred in the $2^{\text {nd }}$ week of August for the two seasons. The results clearly indicated the presence of significant and insignificant correlation coefficient and partial regression between numbers of different insect species and maximum \& minimum temperature and relative humidity during the two successive seasons.
\end{abstract}

Keywords: Ecological Studies, Aphids, Leafhoppers, Whitefly, Cowpea

\section{INTRODUCTION}

Cowpea crop constitute the cheapest source of dietary protein and energy. Large number of insect pests attacks cowpea plants throughout the growing season. Insects are a major factor in the low yield figures of African cowpea crop, and they affect each tissue component and developmental stage of the plant. In severe infestations insect pressure is responsible for over $90 \%$ loss in yield (Jackal and Daoust, 1986, Hashem, 2005 and Patel et al., 2010). The most economic important 
Hemipterous pests are aphids, leafhoppers and whitefly which cause serious damage either directly or indirectly. They feed by piercing plant tissue and penetrating the phloem with needlelike mouthparts. Infested plants become yellowish, stunted, and nonproductive because of direct feeding and the insects' toxic salivary secretions. Also, these insects are efficient vectors of several important virus diseases. The large quantities of honeydew disrupt photosynthesis, which further reduce the yield, AbdElsamed, (2006), Patel et al., (2012) and Cruz et al., (2014).

The present work aimed to survey and investigate the seasonal abundance of the most important common Hemipterous insect pests, aphids, leafhoppers and whitefly at Abo-Hammad district, Sharkia Governorate and study the effect of some climatic factors on the population density of these pests and the efficiency of the different sampling techniques.

\section{MATERIALS AND METHODS}

Ecological studies on the common Hemipterous, aphids, leafhoppers and whiteflies were conducted at Abo-Hammad district, Sharkia Governorate. The area of experiments $\left(510 \mathrm{~m}^{2}\right)$ planted with cowpea during the two successive seasons, 2012 and 2013.

\section{I- Survey and seasonal abundance of aphid, leafhopper and whitefly on cowpea plants}

In the experimental fields, the cowpea was sowed in mid of May for the summer plantation of 2012 and 2013 seasons. The sampling procedures started in the mid of June ( 21 day cowpea plants) and continued till the end of September at weekly intervals. In order to survey the piercing-sucking insects, aphids, leafhoppers and whitefly on cowpea plants, the sweeping nets, plant samples and yellow sticky board trap were used:

\section{1) The yellow sticky board trap}

The yellow sticky board traps were used to survey aphids (Hemiptera: Aphididae), leafhoppers (Hemiptera: Cicadellidae) and whitefly (Hemiptera: Aleyrodidae). The trap of $20 \times 20 \mathrm{~cm}$ yellow paper boards coated with sticky material and hung on wooden rods varied according to the height of cowpea plants through the period of sampling. The trap level was always kept over plant surface with 20 - 30 $\mathrm{cm}$. Three yellow sticky board traps were used in this investigation. Specimens of aphids, leafhoppers and whiteflies were sorted, identified and recorded according to the work of Neilson, (1968), Herakly, (1970) and Hashem, (2005). The counts of captured individuals (aphid, leafhopper and whitefly) were recorded for each trap. 


\section{2) Plant sample}

Plant sample method was used to survey the aphid and whitefly infesting cowpea plants. Concerning the survey of aphids, weekly samples of 25 leaves from the three levels of the plants (lower, middle and upper levels) were taken randomly; the infested leaves were kept in paper bags and investigated in the laboratory. A simple apparatus was used for this purpose, which was consisted of a wooden desk, a white card board paper divided into $4 \mathrm{~cm}$. a part column put in the bottom on which a glass plate was placed and the upper surface of the glass plate was allowed to be wet with fine droplets of water to reduce the movement of counted aphids, (Hegab et al., 1987). The plant leaves were carefully shaken on the plate and the aphids were counted using a small brush in each column. With regard to whitefly, the total number of adults was directly counted on the plant samples in the early morning. In the laboratory by using the stereoscopic-microscope, the immature stages (nymphs and pupae) on both leaf surfaces were examined, counted and recorded.

\section{3) The sweeping net}

The sweeping net was used to survey the leafhoppers infesting cowpea plants. The sweeping net dimensions are $35 \mathrm{~cm}$ diameter and $60 \mathrm{~cm}$ deep. Each sample consisted of 100 double strokes were taken at random. The specimens collected by the sweeping nets were recorded per each sample.

\section{II- Effect of certain climatic factors (maximum temperature, minimum temperature and relative humidity) on the population density of the dominant piercing-sucking insects infesting cowpea plants}

The daily records of both maximum and minimum temperature degrees along with relative humidity during 2012 and 2013 seasons were obtained from the Agrometeorological station at Zagazig city.

The relationship between the weekly mean numbers of collected Hemipterous insects and the corresponding weekly means of maximum, minimum temperatures and relative humidity were estimated. Partial regression was applied to show the effect of each factor on the population density of aphid, leafhopper and whitefly. The results obtained were statistically analyzed; correlation coefficient explained variances and partial regression values were estimated according to Svab, (1973). 


\section{RESULTS AND DISCUSSION}

\section{1-Survey of aphid, leafhopper and whitefly on cowpea plants}

Survey of aphid, leafhopper and whitefly on cowpea plants was studied at AboHammad district, Sharkia Governorate. The data of this study during two successive seasons 2012 and 2013 could be displayed as follow:

\section{i) Aphids (Hemiptera: Aphididae)}

The cowpea aphid, Aphis craccivora Koch and the cotton aphid, A. gossypii (Glov.) were collected by two methods. Data in Table, (1) revealed that the plant samples proved to be the most efficient method for collecting aphid species than yellow sticky board trap. The most extensive infestations by A. craccivora (7627 and 6709 individuals) were recorded on cowpea plants during the experimental seasons of 2012 and 2013, respectivily. Also, the total numbers recorded of A. gossypii were 2431 and 2168 individuals through 2012 and 2013 seasons, respectivily. The present results agreed with those obtained El-Gindy, (2002), Abd-Elsamed, (2006), Ali et al., (2013) and El-Khayat et al., (2014) who found that the aphids $A$. craccivora and $A$. gossypii infesting cowpea plants.

\section{ii) Leafhoppers (Hemiptera: Cicadellidae)}

The data presented in Table, (1) showed the total numbers of three leafhoppers species collected by two different methods, i.e. sweeping net and yellow sticky board trap. These leafhopper species were:

(1) The green leafhopper, Empoasca decipiens (Paoli)

(2) The green leafhopper, E. decedens .

(3) Cicadulina chinai (Ghauri)

The results revealed that sweeping net proved to be more efficient for collecting leafhoppers than sticky board trap during the two successive seasons. The methods of collections appeared the most extensive infestation by $E$. decipiens and $E$. decedens on cowpea during the two successive seasons, respectively, compared by $C$. chinai.

The present results agree with those obtained by El- Gindy, (2002) and AbdElsamed, (2006) who surveyed the aforementioned hemipterous insects on leguminous plants.

\section{iii) Whitefly (Hemiptera: Aleyrodidae)}

Data presented in Table, (1) showed the total numbers of whitefly, B. tabaci collected by two different methods, plant sample and yellow sticky board trap in the investigated areas. Data in Table, (1) revealed that the plant sample was more convenient to whitefly than the other method during the two successive seasons. It 
was clear that the higher infestation by the whitefly, B. tabaci was recorded on cowpea during the first season, 2012. The present result agreed with those obtained Abd-Elsamed, (2006) and El-khayat et al., (2014).

Table 1. Total numbers of aphid, leafhopper and whitefly infesting cowpea plants at Abo-Hammad, Sharkia Governorate collected by using plant sample and yellow sticky board trap and Sweeping net during 2012 and 2013 seasons

\begin{tabular}{|c|c|c|c|c|c|c|}
\hline \multirow[t]{2}{*}{ Insects } & \multicolumn{2}{|c|}{ P. S. } & \multicolumn{2}{|c|}{ Y. S. B. T } & \multicolumn{2}{|c|}{ S. N. } \\
\hline & 2012 & 2013 & 2012 & 2013 & 2012 & 2013 \\
\hline Aphis craccivora & 7627 & 6709 & 899 & 764 & - & - \\
\hline A. gossypii & 2431 & 2168 & 408 & 394 & - & - \\
\hline Empoasca decipiens & - & - & 161 & 131 & 901 & 805 \\
\hline E. decedens & - & - & 74 & 81 & 497 & 521 \\
\hline Cicadulina chinai & - & - & 42 & 35 & 160 & 120 \\
\hline Bemisia tabaci (adult) & 1415 & 1244 & 440 & 398 & - & - \\
\hline B. tabaci (immature) & 2898 & 2065 & - & - & - & - \\
\hline
\end{tabular}

P.S. = Plant sample Y.S.B.T. $=$ yellow sticky board trap $\quad$ S.N. $=$ Sweeping net

\section{Seasonal abundance of aphid, leafhopper and whitefly infesting cowpea plants}

\section{1) Aphid}

\section{i) The cowpea aphid, Aphis craccivora Koch}

The numbers of aphid fluctuated on cowpea plants with general increase showing one peak Fig., (1). The peak occurred at the end of July with a mean numbers 865 and 663 individuals/sample in 2012 and 2013 seasons, respectively at mean temperature of $28.45^{\circ} \mathrm{C}$ with $57.25 \%$ R.H. and $28.50^{\circ} \mathrm{C}$ with $50.35 \%$ R.H. for the two seasons, respectively.

Regarding the weekly counts of aphid on cowpea plants, its clear that this species was more abundant during 2012 than 2013 (Fig., 1). Similar results were found by Hashem, (1997), El-Gindy, (2002), Ali et al., (2013) and El-Khayat et al., (2014).

\section{ii)The cotton aphid, Aphis gossypii (Glover)}

Fig., (1) showed that this aphid species has one peak recorded 

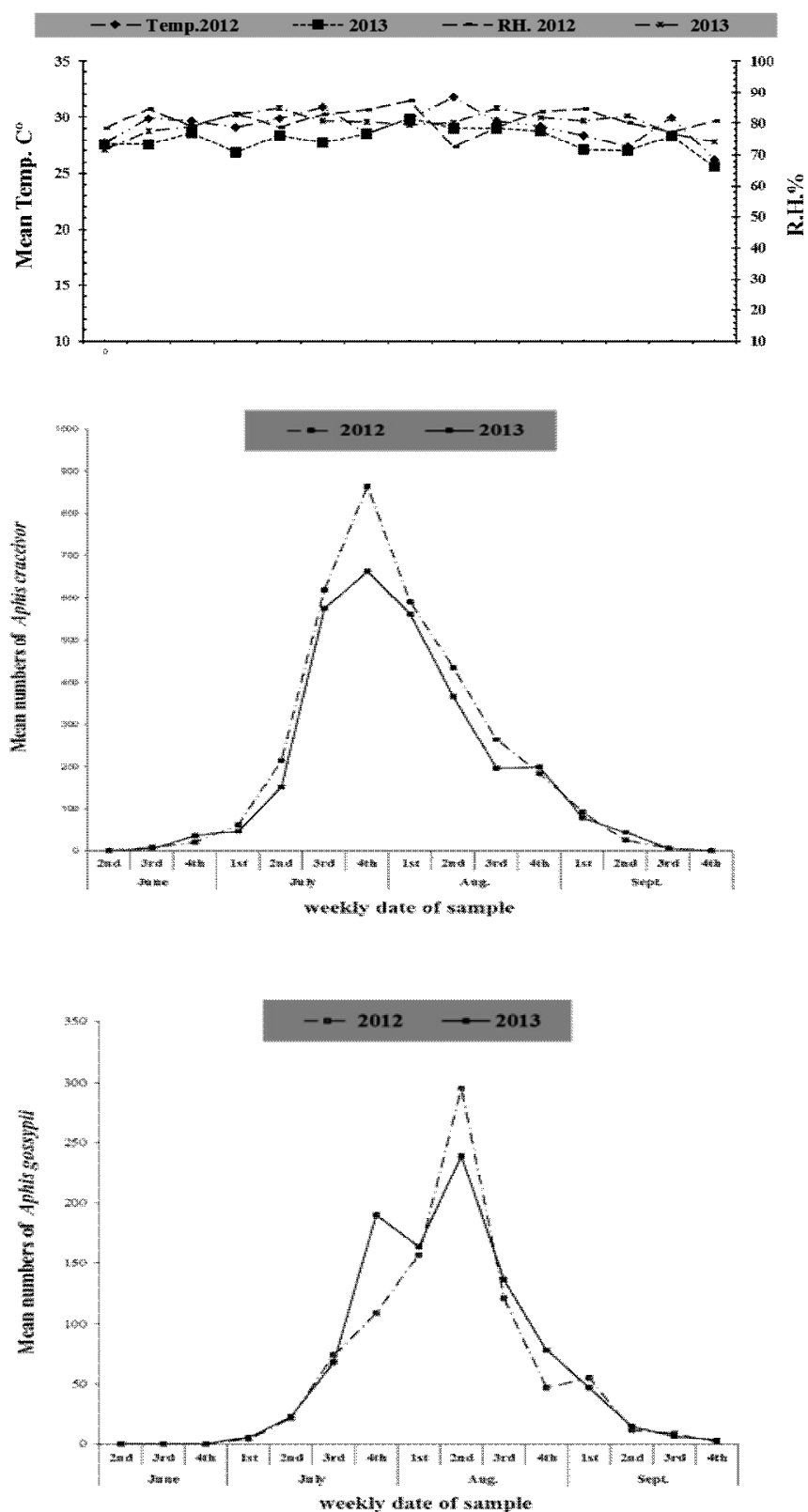

Fig. 1. Population density of Aphis craccivora and A. gossypii infesting cowpea plants collected by using plant sample at Abo - Hammad, Sharkia Governorate during 2012 and 2013 seasons

in the $2^{\text {nd }}$ week of August with a mean numbers of 295 individuals/sample at mean temperature of $31.79^{\circ} \mathrm{C}$ with $44.79 \%$ R.H. for 2012 season. In the second season, 2013 , two peaks were recorded in the $4^{\text {th }}$ week of July and the $2^{\text {nd }}$ week of August of 190 and 239 individuals/sample at mean temperature $28.50^{\circ} \mathrm{C}$ with $50.35 \%$ and $29.00^{\circ} \mathrm{C}$ with $50.36 \%$ R.H., respectively. The population of $A$. gossypii was slightly higher in the first season (approximately 1.12 folds) than in the second season 
(Table, 1). The population of $A$. craccivora was greater than $A$. gossypii (approximately 3.1 folds) in the both seasons (Table, 1 ).

\section{2) leafhopper}

Regarding the population abundance of leafhopper species on the cowpea plants during, the two study seasons, the numbers of Cicadulina chinai were very few. The study of seasonal abundance was conducted on Empoasca decipiens and E. decedens only.

\section{i) The green leafhopper, Empoasca decipiens (Paoli)}

According to the abundance of E. decipiens individuals on cowpea plants, two peaks were recorded (Fig., 2). The first peak was recorded at the $3^{\text {rd }}$ and $4^{\text {th }}$ week of July with a mean numbers of 61 and 51 individuals/sample were recorded at mean temperature of 30.93 and $28.50^{\circ} \mathrm{C}$ with 52.00 and $50.35 \%$ R.H. for 2012 and 2013 seasons, respectively. The second one occurred at the $3^{\text {rd }}$ week of August with a mean number of 55 and 47 individuals/sample at mean temperature of 29.64, $29.00^{\circ} \mathrm{C}$ with $50.71,56.08 \%$ R.H. for the two seasons of the study, respectively. Regarding the weekly counts of E. decipiens, on cowpea plants, it is clear that this species was more abundant during 2012 than 2013 (Table, 1).

\section{ii) The green leafhopper, Empoasca decedens (Paoli)}

Data in Fig., (2) showed that two peaks of E. decedens were detected during 2012 and 2013 seasons. The first peak occurred at the end of July with a mean number of 27 and 26 individuals /sample at mean temperature of 28.45 and $28.50^{\circ} \mathrm{C}$ with 57.25 and $50.35 \%$ R.H. for the two seasons, respectively. The second one was presented at the end of August with mean numbers of 29 and 28 individuals/sample at mean temperature of 29.15 and $28.80{ }^{\circ} \mathrm{C}$ with 53.40 and $54.00 \%$ R.H. for the two seasons, respectively. Regarding the weekly counts of E. decedens, on cowpea plants, it is clear that this species was more abundant during 2013 than 2012 (Table, 1). Similar results were found by Hashem, (1997), El-Gindy, (2002). The results indicated that E. decipiens had two peaks, (at the $3^{\text {rd }}, 4^{\text {th }}$ week of July and at the $3^{\text {rd }}$ week of August), while E. decedens had two peaks, ( at the end of July and at the end of August) on cowpea plants during 2012 and 2013 seasons, respectively.

These results agreed with the findings of El-Gindy, (2002), Hashem, (2005) and Abd-Elsamed, (2006), who mentioned that $E$. decipiens had two peaks on leguminous and solanaceous plants in summer plantation. 

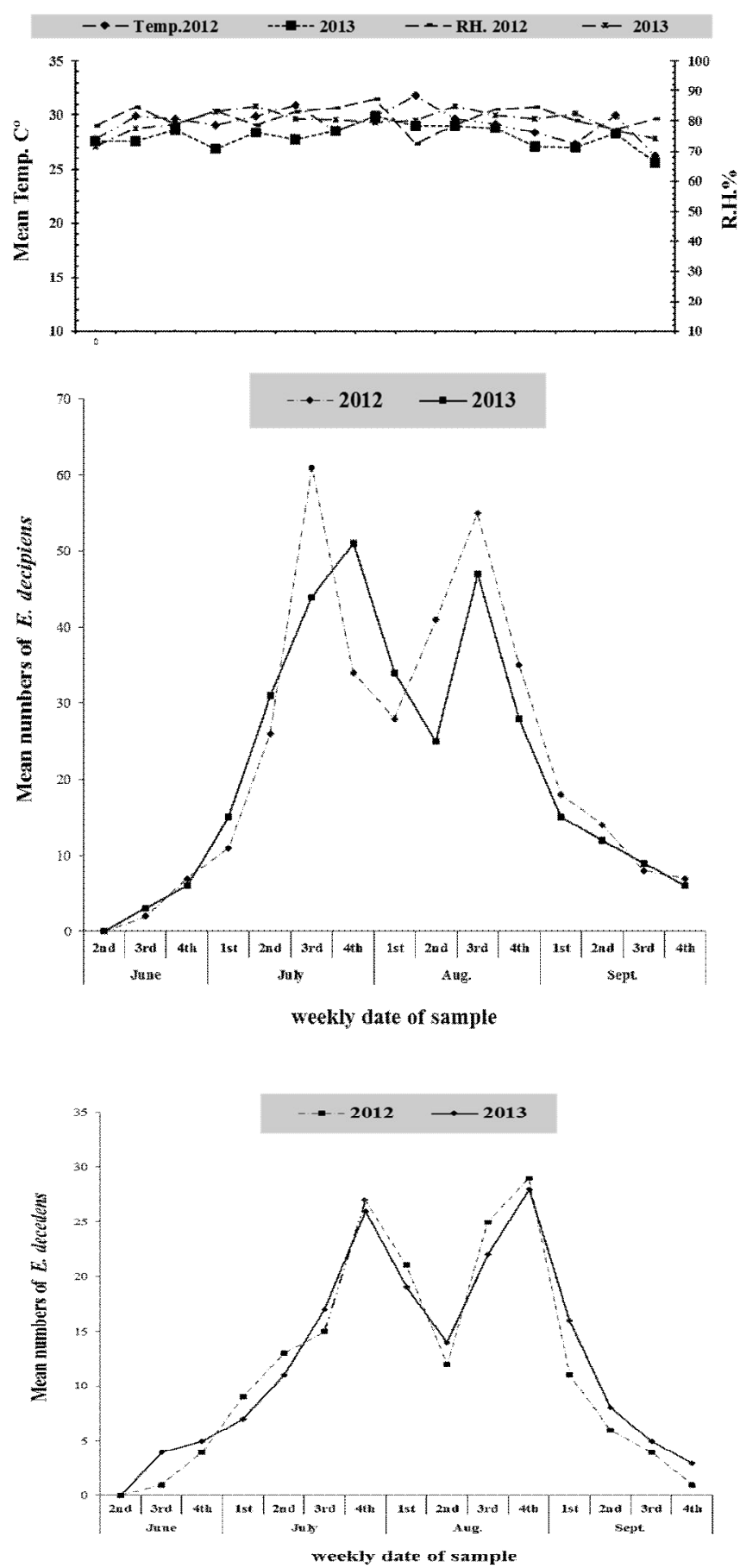

Fig. 2. Population density of leafhopper, Empoasca decipiens and E. decedens infesting cowpea plants collected by using sweeping net at Abo Hammad, Sharkia Governorate during 2012 and 2013 seasons 


\section{3) The whitefly, Bemisia tabaci (Genn.) \\ i) Immature stage}

Regarding the abundance of B. tabaci immature stages in 2012 and 2013 seasons Fig., (3) showed that two peaks of population density on cowpea plants were occurred. The first peak was obtained at the end of July with a mean numbers of 133 and 210 individuals/sample in 2012 and 2013 seasons, respectively at mean temperature of $28.45^{\circ} \mathrm{C}$ with $57.25 \%$ R.H. and $28.50^{\circ} \mathrm{C}$ with $50.35 \%$ R.H. for the two seasons, respectively. The second one was noticed at the $3^{\text {rd }}$ week of August with a mean numbers of 157 and 199 individuals/sample at mean temperature of $29.64^{\circ} \mathrm{C}$ with $50.71 \%$ R.H. and $29.00^{\circ} \mathrm{C}$ with $56.08 \%$ R.H. for the two seasons, respectively. Generally the numbers of immature individuals were little higher in the second peak, 1.6 and 1.3 folds than in the first one in both seasons, respectively.

\section{ii) Adult stage}

Fig., (3) indicated that mean numbers of adults/sample increased until reached its peak at the $3^{\text {rd }}$ week of July with a mean number of 58 and 46 individuals/sample at mean temperature of $30.93^{\circ} \mathrm{C}$ with $52.00 \%$ R.H. and $27.71^{\circ} \mathrm{C}$ with $54.57 \%$ R.H. for 2012 and 2013 seasons, respectively. The second peak of the population density occurred in the $2^{\text {nd }}$ week of August with a mean number of 68 and 54 individuals/sample at mean temperature of $31.79^{\circ} \mathrm{C}$ with $44.79 \%$ R.H. and $29.00^{\circ} \mathrm{C}$ with $50.36 \%$ R.H. for the two seasons, respectively. Regarding the weekly counts, it is clear that this species was more abundant during 2012 than 2013 (Table, 1).

\section{Effect of certain climatic factors, (maximum temperature, minimum temperature and mean relative humidity) on the population density of the dominant piercing-sucking insects infesting cowpea plants}

\section{1) Aphid}

\section{i) The cowpea aphid, Aphis craccivora Koch}

In Table, (2) the mean numbers of $A$. craccivora population was positive and insignificant correlation with maximum temperature, $r_{1}=0.3158$ and 0.3696 in 2012 and 2013 seasons, respectively. The relationship between the numbers of $A$. craccivora population and minimum temperature was positive and significant ( $r_{2}$ $\left.=0.5912^{*}\right)$ in 2012 but it was positive and insignificant $\left(r_{2}=0.3695\right)$ in 2013 season. There was positive and insignificant correlation coefficient between the population density of $A$. craccivora and relative humidity, $\mathrm{r}_{3}=0.3120$ and 0.4003 in 2012 and 2013 seasons, respectively. The partial regression between $A$. craccivora population and maximum temperature was positive and insignificant $\left(b_{1}=0.0018\right.$ and 0.0016 in 2012 and 2013 seasons, respectively). Also, the partial regression between the numbers of $A$. craccivora population and minimum temperature was positive but it 
was insignificant ( $b_{2}=0.0026$ and 0.0011 in 2012 and 2013 seasons, respectively). There was positive and insignificant partial regression between the numbers of $A$. craccivora population and relative humidity ( $b_{3}=0.0045$ and 0.0610 in 2012 and 2013 seasons, respectively).
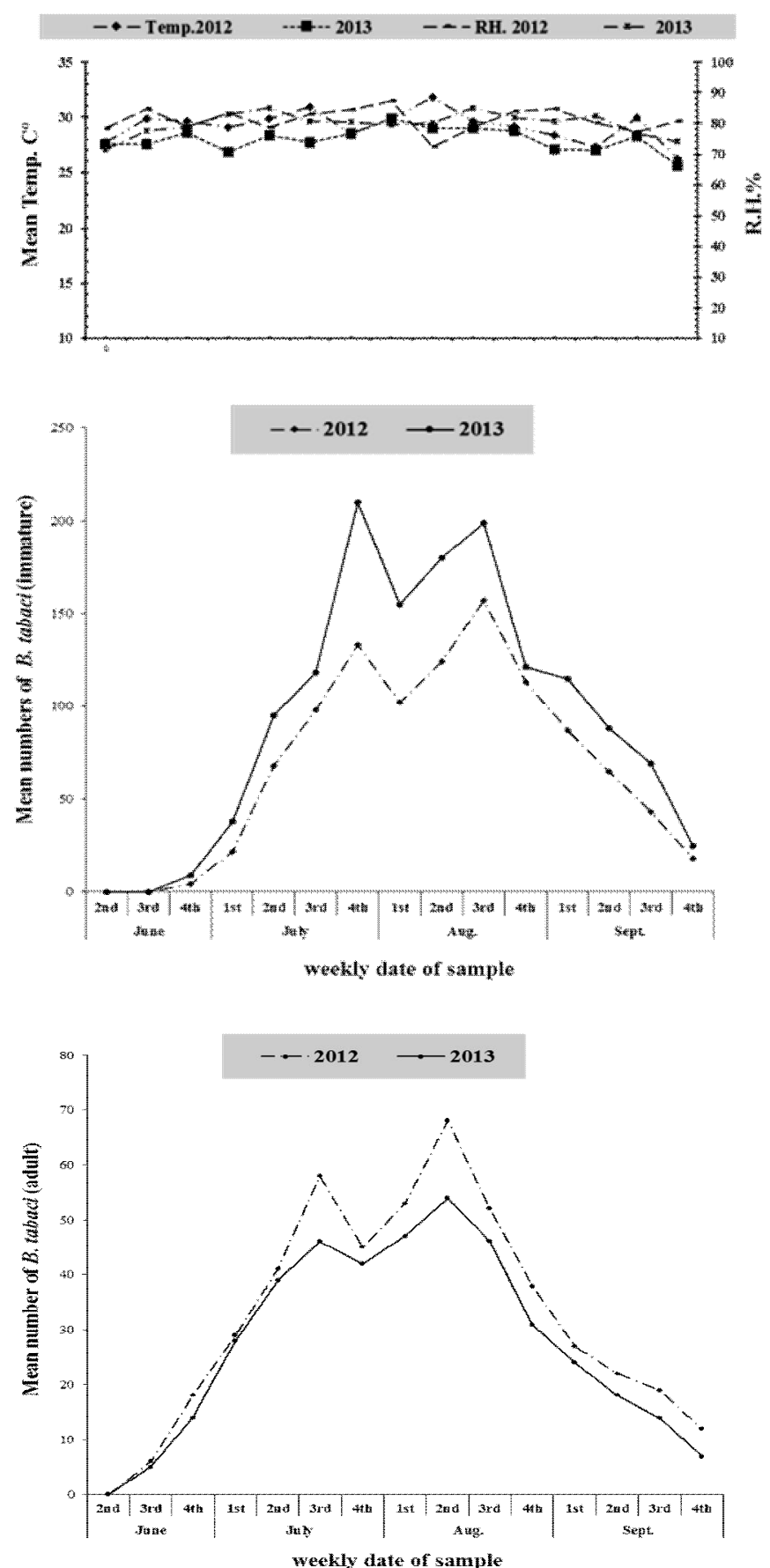

Fig. 3. Population density of the whitefly, Beimsia tabaci (immature and adult) infesting cowpea plants collected by using plant sample at Abo - Hammad, Sharkia Governorate during 2012 and 2013 seasons 
Table 2. Partial regression and simple correlation coefficient between maximum \& minimum temperature and relative humidity and total numbers of Hemipterous insects infesting cowpea plants at Abo-Hammad, El-Sharkia governorate during 2012 and 2013 seasons.

\begin{tabular}{|c|c|c|c|c|c|c|c|c|c|c|c|c|}
\hline \multirow{3}{*}{ Insects } & \multicolumn{6}{|c|}{ Simple correlation } & \multicolumn{6}{|c|}{ Partial regression } \\
\hline & \multicolumn{3}{|c|}{2012} & \multicolumn{3}{|c|}{2013} & \multicolumn{3}{|c|}{2012} & \multicolumn{3}{|c|}{2013} \\
\hline & $r_{1}$ & $r_{2}$ & $r_{3}$ & $r_{1}$ & $r_{2}$ & $r_{3}$ & $b_{1}$ & $b_{2}$ & $b_{3}$ & $b_{1}$ & $b_{2}$ & $b_{3}$ \\
\hline Aphis craccivora & 0.3158 & $0.5912^{*}$ & 0.3120 & 0.3696 & 0.3695 & 0.4003 & 0.0018 & 0.0026 & 0.0045 & 0.0016 & 0.0011 & 0.0610 \\
\hline A. gossypii & 0.3914 & $0.7728^{* * *}$ & 0.3347 & $0.5163^{*}$ & $0.5712^{*}$ & 0.0217 & $19.0039^{*}$ & $44.4862^{* *}$ & -8.3570 & 28.2784 & 45.6184 & 0.5407 \\
\hline Empoasca decipiens & 0.3691 & $0.7366^{* *}$ & -0.1285 & 0.3868 & $0.5603^{*}$ & 0.9794 & 4.135 & $9.758^{* *}$ & -0.7408 & 4.4629 & 9.4261 & 2.6087 \\
\hline E. decedens & 0.0653 & $0.6024^{*}$ & 0.2311 & 0.4590 & $0.5688^{*}$ & 0.4299 & 0.3764 & $4.1136^{* *}$ & 0.6843 & 2.7635 & 4.9925 & 1.1766 \\
\hline Bemisia tabaci (immature) & 0.3031 & $0.8077^{* *}$ & 0.2947 & 0.3042 & $0.558^{*}$ & 0.4801 & 0.0119 & 0.0241 & 0.0288 & 0.0059 & 0.0078 & 0.0318 \\
\hline B. tabaci (adult) & 0.3067 & $0.8029^{* *}$ & 0.2996 & 0.3095 & $0.5664^{*}$ & 0.3138 & 0.0276 & 0.0551 & 0.0672 & 0.0250 & 0.3270 & 0.0861 \\
\hline
\end{tabular}

$r_{1}, b_{1}=$ correlation coefficients and partial regression between maximum temperature and number of insects

$r_{2}, b_{2}=$ correlation coefficients and partial regression between minimum temperature and number of insects

$r_{3}, b_{3}=$ correlation coefficients and partial regression between relative humidity and number of insects 


\section{ii) The cotton aphid, Aphis gossypii (Glov.)}

The mean numbers of $A$. gossypii population was positive and insignificant correlation with maximum temperature $\left(r_{1}=0.3914\right)$ in 2012 season, while it was positive and significant $\left(r_{1}=0.5163^{*}\right)$ in 2013 season. The relationship between the mean numbers of $A$. gossypii and minimum temperature was positive and highly significant in 2012 season $\left(r_{2}=0.7728^{* * *}\right)$ and it was positive and significant $\left(r_{2}=0.5712^{*}\right)$ in 2013 season. There was positive and insignificant correlation coefficient between the population density of $A$. gossypii and relative humidity $\left(r_{3}=0.3347\right.$ and 0.0217$)$ in 2012 and 2013 seasons, respectively. The partial regression between A. gossypii population and maximum temperature was positive and significant $\left(b_{1}=19.0039 *\right)$ in 2012 but positive and insignificant $\left(b_{1}=28.2784\right)$ in 2013 season. The partial regression between the mean numbers of $A$. gossypii and minimum temperature was positive and highly significant $\left(b_{2}=44.4862^{* *}\right)$ in 2012 season, but positive and insignificant $\left(b_{2}=45.6184\right)$ in 2013 season. There was negative and insignificant partial regression between the mean numbers of $A$. gossypii and relative humidity ( $b_{3}$ $=-8.3570)$ in 2012 season, while it was positive and insignificant $(b 3=0.5407)$ in 2013 season.

\section{2) Leafhopper}

\section{i) The green leafhopper, Empoasca decipiens (Paoli)}

The correlation coefficient between $E$. decipiens population and maximum temperature was positive and insignificant $\left(r_{1}=0.3691\right.$ and 0.3868$)$ in 2012 and 2013 seasons, respectively. Concerning the relationship between $E$. decipiens population and minimum temperature, there was positive and high significant correlation ( $r_{2}=$ $\left.0.7366^{* *}\right)$ in 2012 season, but it was positive and significant $\left(r_{2}=0.5603^{*}\right)$ in 2013 season. The correlation coefficient between the population of $E$. decipiens and relative humidity was negative and insignificant $\left(r_{3}=-0.1285\right)$ in 2012 but it was positive and insignificant $\left(r_{3}=0.9794\right)$ in 2013 season. The partial regression between the population of $E$. decipiens and maximum temperature was positive and insignificant ( $b_{1}=4.135$ and 4.4629) in 2012 and 2013 seasons, respectively. There was positive and highly significant partial regression between $E$. decipiens population and minimum temperature $\left(b_{2}=9.758^{* *}\right)$ in 2012 season, while it was positive and insignificant ( $b_{2}$ $=9.4261)$ in 2013 season. The partial regression between $E$. decipiens population and relative humidity was negative and insignificant $\left(b_{3}=-0.7408\right)$ in 2012 season, but it was positive and insignificant $\left(b_{3}=2.6087\right)$ in 2013 season.

\section{ii) The green leafhopper, Empoasca decedens (Paoli)}

The correlation coefficient between $E$. decedens population and maximum temperature was positive and insignificant, $\left(r_{1}=0.0653\right.$ and 0.4590$)$ in 2012 and 
2013 seasons, respectively. Concerning the relationship between $E$. decedens population and minimum temperature, there was positive and significant correlation $\left(r_{2}=0.6024^{*}\right.$ and $\left.0.5688^{*}\right)$ in 2012 and 2013 seasons, respectively. The correlation coefficient between the population of $E$. decedens and relative humidity was positive and insignificant ( $r_{3}=0.2311$ and 0.4299 ) in 2012 and 2013 seasons, respectively. The partial regression between population of $E$. decedens population and maximum temperature was positive and insignificant $\left(b_{1}=0.3764\right.$ and 2.7635) in 2012 and 2013 seasons, respecyively. There was positive and highly significant partial regression between $E$. decedens population and minimum temperature $\left(b_{2}=4.1136^{* *}\right)$ in 2012 season, whereas it was positive and insignificant $\left(b_{2}=4.9925\right)$ in 2013 seasonre. The partial regression between $E$. decedens population and relative humidity was positive and insignificant ( $b_{3}=0.6843$ and 1.1766$)$ in 2012 and 2103 seasons, respectively.

\section{3) The whitefly, Bemisia tabaci (Genn.)}

\section{i) Immature stage}

Positive and insignificant correlation coefficient was found between immature stages of $B$. tabaci population and maximum temperature $\left(r_{1}=0.3031\right.$ and 0.3042$)$ in 2012 and 2013 seasons, respectively. The correlation coefficient between B. tabaci population and minimum temperature was positive and highly significant ( $\mathrm{r}_{2}=$ $\left.0.8077^{* *}\right)$ in 2012 season, but it was positive and significant $\left(r_{2}=0.5580^{*}\right)$ in 2013 season. The correlation coefficient between $B$. tabaci population and relative humidity was positive and insignificant ( $r_{3}=0.2947$ and 0.4801$)$ in 2012 and 2013 seasons, respectively. The partial regression between the mean numbers of $B$. tabaci and maximum temperature were positive and insignificant $\left(b_{1}=0.0119\right.$ and 0.0059$)$ in 2012 and 2013 seasons, respectively. Positive and insignificant partial regression was found between mean numbers of $B$. tabaci and minimum temperature $\left(b_{2}=0.0241\right.$ and 0.0078 ) in 2012 and 2013 seasons, respectively. The partial regression between the mean numbers of $B$. tabaci and relative humidity was positive and insignificant (b3 $=0.0288$ and 0.0318 ) in 2012 and 2013 seasons, respectively.

\section{ii) Adult stage}

The correlation coefficient between the adult stage of $B$. tabaci population and maximum temperature was positive and insignificant $\left(r_{1}=0.3067\right.$ and 0.3095$)$ in 2012 and 2013 seasons, respectively. While it was positive and highly significant between the population of $B$. tabaci adults and minimum temperature $\left(r_{2}=0.8029^{* *}\right)$ in 2012 season, but it was positive and significant $\left(r_{2}=0.5664^{*}\right)$ in 2013 season. The correlation coefficient between B. tabaci population and relative humidity were positive and insignificant $\left(r_{3}=0.2996\right.$ and 0.3138) in 2012 and 2013 seasons, respectivly. The partial regression between the mean numbers of $B$. tabaci population and maximum temperature was positive and 
insignificant ( $b_{1}=0.0276$ and 0.0250 ) for the two seasons, respectively. Also it was positive and insignificant between $B$. tabaci population and minimum temperature ( $b_{2}$ $=0.0551$ and 0.3270 ) for the both seasons, respectively. The partial regression recorded between mean numbers of $B$. tabaci population and relative humidity was positive and insignificant $\left(b_{3}=0.0672\right.$ and 0.0861 ) in 2012 and 2013 seasons, respectively. The results agreed with Khalifa and Elkhidir, (1965), Lal, (1981) and Aldyhim and Khalil, (1993) who found that the change in the enviromental factors from year to year (such as maximum and minimum daily temperature, relative humidity, direction and speed of wind, rain fall, ....etc.) effects the population density and dynamics of insect pests and the occurrence of the natural enemies. Mondal and Gill, (2010) mentioned that whitefly population was severely influenced by weather parameters i.e., temperature, rainfall and relative humidity. The rainfall adversely effected population, followed by temperature and relative humidity. Ali et al., (2013) showed that temperature and relative humidity had different effects on insects under investigation, significant with some insects and insignificant with the other.

\section{Combined effects of meteorological factors and path analysis}

The effect of maximum, minimum temperatures and mean relative humidity on aphids, leafhoppers and whitefly population was estimated by calculating the partial regression analysis (Least Square Regression equation). Values of explained variance by the three aforementioned meteorological factors (Table, 3) showed that the considered factors have played a conspicuous role in detecting the activity of these pests during the study seasons. These results indicated that the tested meteorological factors play a great role in regulating the population density and seasonal abundance of such insect pests. Similar findings were reported by Hegab, (1997 and 2001), ElGindy, (1997 and 2002), Hashem, (1997 and 2005), Abd-Elsamed, (1999 and 2006), which greatly correspond with the present results.

The method of path coefficient included the independent variable i.e. maximum temperature, minimum temperature and mean relative humidity. Path analysis was practiced in order to find out the relative importance of these variable in contributing numbers of insects. Table, (3) presented the relative importance in contributing numbers of insects as recorded in percentage of variation of maximum temperature, minimum temperature and mean relative humidity in 2012 and 2013 seasons. 
Table 3. Explained and unexplained variance and the effects of maximum , minimum temperature and mean relative humidity on the total numbers of hemipterous insects infesting cowpea plants at Abo-Hammad, Sharkia, Governorate during 2012 and 2013 seasons.

\begin{tabular}{|l|c|c|c|c|}
\hline \multirow{2}{*}{ Insects } & \multicolumn{2}{c|}{ Explained variance } & \multicolumn{2}{c|}{ Unexplained variance } \\
\cline { 2 - 5 } & 2012 & 2013 & 2012 & 2013 \\
\hline Aphis craccivora & 0.4459 & 0.2985 & 0.5541 & 0.7015 \\
\hline A. gossypii & 0.7315 & 0.34402 & 0.2685 & 0.65598 \\
\hline Empoasca decipiens & 0.5690 & 0.4935 & 0.4310 & 0.5065 \\
\hline E. decedens & 0.5560 & 0.4887 & 0.4440 & 0.5113 \\
\hline $\begin{array}{l}\text { Bemisia tabaci } \\
\text { (immature) }\end{array}$ & 0.7533 & 0.3390 & 0.2467 & 0.6610 \\
\hline B. tabaci (adult) & 0.7924 & 0.4564 & 0.2076 & 0.5436 \\
\hline
\end{tabular}

REFERENCES

1. Abd-Elsamed, A. A. 1999. studies on certain piercing sucking insect vectors of plant pathogenic diseases M.Sc. Thesis, Fac. Agric., Zagazig Univ. Egypt. 176 pp.

2. Abd-Elsamed, A. A. 2006. studies on some homopterous insect vectors of plant diseases. Ph.D. Thesis, Fac. Agric., Zagazig Univ. Egypt. 387pp.

3. Aldyhim, Y. N. and A. F. Khalil. 1993. Influence of temperature and day length on population development of Aphis gossypii on Cucurbita peop. Entomol. Exp. Appl. 67, 167-172.

4. Ali, SH. A. M; A. A. A. Saleh and Nadia E. Mohamed. 2013. Aphis craccivora Koch and predators on faba bean and cowpea in newly reclaimed areas in Egypt. Egypt .J. Agric .91 (4):1423-1437.

5. Cruz, P. L.; E. L. L., Baldin and M. J. P., Castro. 2014. Characterization of antibiosis to the silver leaf whitefly, Bemisia tabaci biotype B (Hemiptera: Aleyrodidae) in cowpea entries. J. Pest Sci. 87: 639 - 645.

6. El-Gindy, M. A. 1997. Studies on certain homopterous insect infesting some vegetable in Dakahlia Governorate. M. Sc. Thesis, Fac. Agric, Zagazig Univ. Egypt.172 pp.

7. El - Gindy, M. A. 2002. Studies on certain homopterous insect vectors of plant pathogenic diseases. ph. D. Thesis, Fac. Agric. Zagazig Univ. Egypt. 263 pp. 
8. El-Khayat, E. F.; M. M., Ghallab and B.S., Wahba. 2014. The effect of different types and rates of fertilizers on the population density of sap sucking pests inhabiting cowpea fields. Arab Universities J. Agric. Sci. 22(2): 431 - 436.

9. Hashem, M. S. 1997. Studies on certain insect's infesting some vegetable plants in Sharkia Governorate. M. Sc. Thesis, Fac. Agric. Zagazig Univ. Egypt. 167 pp.

10. Hashem, M. S. 2005. Studies on certain piercing-sucking insects infesting some vegetable crops. Ph.D. Thesis, Fac. Agric. at Moshtohr Zagazig Univ. Egypt. 323 pp.

11. Hegab, A. M.; I. M., Kelany and M. M., EI-Maghraby. 1987. Survey of leafhoppers and planthoppers infesting maize plants by using three sampling techniques in newly reclaimed sandy areas at Salhia district, Egypt. Mina J. Agric. Res. 9 (2): 945-953.

12. Hegab, Ola I. M. S. 1997. Studies on certain homopterous insects vector of plant pathogenic diseases. M. Sc. Thesis, Fac. Agric. Zagazig Univ. Egypt. 134 pp.

13. Hegab, Ola I. M. S. 2001. Studies on certain insect vectors of plant pathogenic agents. Ph.D. Fac. Agric. Zagazig Univ. Egypt. 323 pp.

14. Herakely, F. A. 1970. Studies on jassids infesting vegetables in Egypt. M.Sc. Thesis, Fac. Agric., Ain Shams Univ. Egypt. 221 pp.

15. Jackal, L. E. N. and R. A., Daoust. 1986. Insect pests of cowpeas. Ann. Rev. Entomol. 31, 95-119.

16. Khalifa, A. and E., El-Khidir. 1965. Biological studies on Triaeurodes lubia and Bemisia tabaci (Aleyrodidae). Bull. Ent. Soc. Egypt, 48,115-129.

17. Lal, S. S. 1981. An ecological study of the whitefly, Bemisia tabaci (Genn.) population on cassava, Manihot esculenta. Pestol. 5(1), 11-17.

18. Mondal, S. and C. K., Gill. 2010. Influence of weather parameters on the incidence of Cowpea Golden Mosaic Virus and its vector, Bemisia tabaci (Gennadius). Indian J. Entomol. 72(1): $79-83$.

19. Neilson, M. W. 1968. The leafhopper vectors of phytopathogenic viruses (Homoptera: Cicadilidae) taxonomy. Biology and virus transmission. Agric. Res. Ser. M.S. Dept. Agric. 89. 386.

20. Patel, S. K.; B. H., Patel; D. M., Korat and M. R., Dabhi. 2010. Walpers in relation to weather parameters. Karnataka J. Agric. Sci. 23(3): 497 - 499.

21. Patel, P. S.; I. S., Patel; B., Panickar and Y., Ravindrababu. 2012. Management of sucking pests of cowpea through seed treatment. Trends in Biosciences. 5(2): $138-139$.

22. Svab, J., 1973. Biometrical modszerek a kutatashan, Mezogozadasagi Kiado, Budapest, $77-173$. 


\section{در اسات إيكولوجية على بعض الحشرات الثاقبة الماصة التي تصيب اللوبيا في محافظة الشرقية بمصر}

عزت فرج الخياط ' ، رشا علي الحصري' و أسماء عبد الحميد عبد الله فضل ‘

$$
\text { r- r- كلبة الزراعة - جامعة بنها البحوث الزراعبة - معهد بحوث وقاية النباتات - الدقى - جيزة }
$$

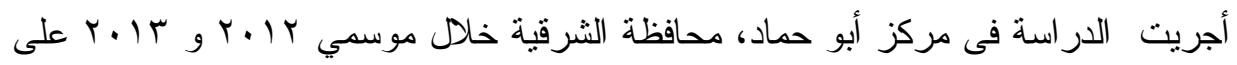

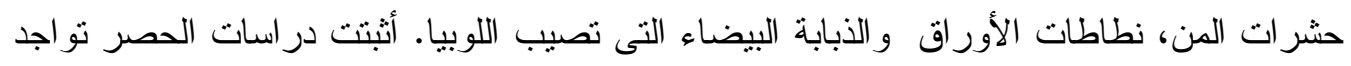

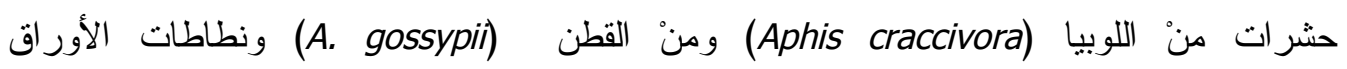
Bemisia (Empoasca decipiens, E. decedens and Cicadulina chinai)

-(tabaci

\section{أوضحت نتائج دراسة الوفرة الموسمية للأنواع السائدة ما يلى:}

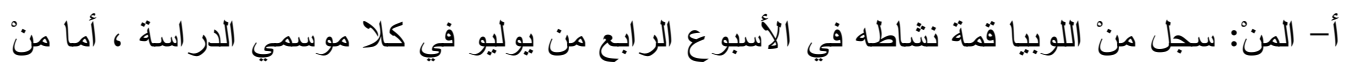

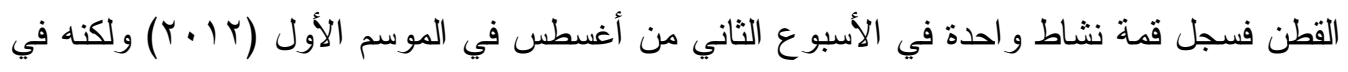
الموسم الثاني سجل قمتي نشاط، كانت قمة نشاطه الأولى فى الأسبوع الرابع من يوليو أما القمة الثة

$$
\text { الثانية فسجلت في الأسبوع الثاني من أغسطس . }
$$

ب - نطاطات الأوراق: سجل (E. decipiens) قمتي نشاط في كلا موسمي الدراسة، كانت القمة الأولى فى الأسبوع الثالث والرابع من شهر يوليو لكلا الموسمين على التوالي. أما القمة الثانية فسجلت في الأسبوع الثالث من شهر أغسطس خلال موسمي الدراسة. كما سجل قمتي نشاط لحشرة في الأسبوع الرابع لكلٍ من شهري يوليو وأغسطس على النو الي خلال موسمي

ج - الذبابة البيضاء: سجلت كلٍ من الأطوار الغير كاملة و الأطوار الكاملة قمني نشاط على لئى

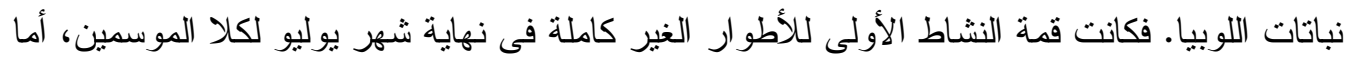
القمة الثانية فكانت فى الأسبوع الثالث من شهر أغسطس في كلا الموسمين. أما الحشر ات الكاملئل سجلت قمتها الأولى في الأسبوع الثالث من شهر يوليو لكلا الموسمين، وسجلت القمة الثانية في

$$
\text { الأسبوع الثاني من شهر أغسطس في كلا الموسمين. }
$$

تم دراسة نأثير كلٍ من الحرارة العظمى والحرارة الصغرى و الرطوبة النسبية على الكثافة

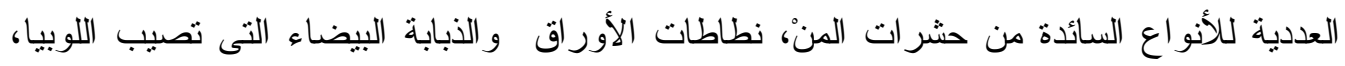

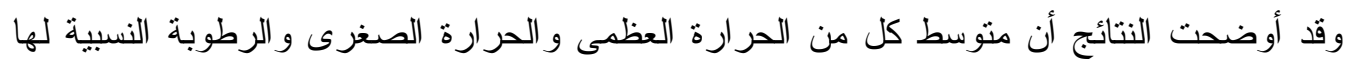
تأثير معنوى على تعداد الحشر ات تحت الدر استة. 